\title{
Acute abdomen caused by greater omentum torsion: A case report and review of the literature
}

\author{
Camilla Cremonini, M.D., Andrea Bertolucci, M.D., Dario Tartaglia, M.D., \\ Francesca Menonna, M.D., Christian Galatioto, M.D., Massimo Chiarugi, M.D.
}

Department of Emergency Surgery Unit, Università Di Pisa, Pisa-Italy

\begin{abstract}
Torsion of the greater omentum is a rare cause of acute abdomen. Based on etiopathogenesis, it can be classified as primary or secondary. However, regardless of the cause, segmentary or diffuse omental necrosis will follow. Preoperative diagnosis is not easy, though abdominal ultrasound and computed tomography (CT) scans may show peculiar features suggestive of omental torsion. Laparoscopic resection of the affected omentum is the treatment of choice. Presently reported was a case of primary omental torsion, in addition to a comprehensive literature review.
\end{abstract}

Keywords: Acute abdomen; greater omentum; laparoscopy; omental infarction; torsion.

\section{INTRODUCTION}

Omental infarction is a rare cause of acute abdomen. The infarction is primarily caused by torsion of the greater omentum, and can be classified as primary, first described by Eitel in 1899 , or as secondary to other diseases. ${ }^{[I]}$ It mainly affects adults, occurring in men twice as frequently as in women, with the majority of those affected being overweight. ${ }^{[2]}$ Preoperative diagnosis is difficult, as symptoms are unspecific and may easily be mistaken for those of other diseases, such as acute appendicitis, acute cholecystitis, or right-sided diverticulitis. [3,4] However, the increasing spread of high-quality imaging, particularly computed tomography (CT), has allowed for preoperative diagnosis to be performed much more often..$^{[5]}$ Presently described was a case of omental infarction caused by primary torsion. A review of the literature concerning this unusual cause of acute abdomen was also included.

\section{CASE REPORT}

A 28-year-old male presented to the emergency department

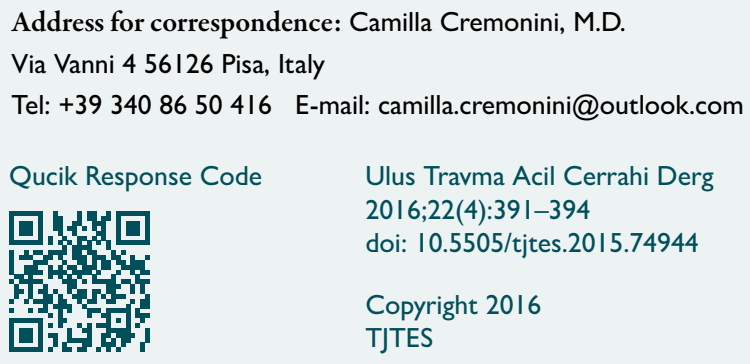

with a 4-day history of abdominal pain, mainly localized in the right quadrants, associated with anorexia. No nausea nor vomiting were present. The patient had no previous abdominal surgery in his medical history, but reported mild symptoms consistent with gastritis that had begun 4 months prior. The patient was hemodynamically stable and apyretic. The abdomen was soft, not distended, showing tenderness in the right iliac fossa and the right upper quadrant, with physical signs of peritoneal irritation.

Laboratory investigation was normal, revealing no other abnormalities. Abdominal ultrasound showed a roundish hyperechoic lesion in correspondence with the right colon, in the absence of fluid effusion. Abdominal CT scan confirmed the presence of an oval thickening of fat tissue containing convoluted and twisted blood vessels in the right abdomen. These $\mathrm{CT}$ features raised suspicion of an area of omental infarction (Figure I).

Laparoscopy confirmed hemorrhagic infarction with necrosis of the section of the greater omentum attached to the proximal transverse colon; the remainder of the omentum appeared normal. A torsion point with occlusion of blood vessels tributary to the infarcted omentum was identified, and necrotic tissue was resected (Figure 2). No other concomitant intraperitoneal disease was identified. Course of treatment was unremarkable, and the patient was discharged on day 2 in healthy condition. 

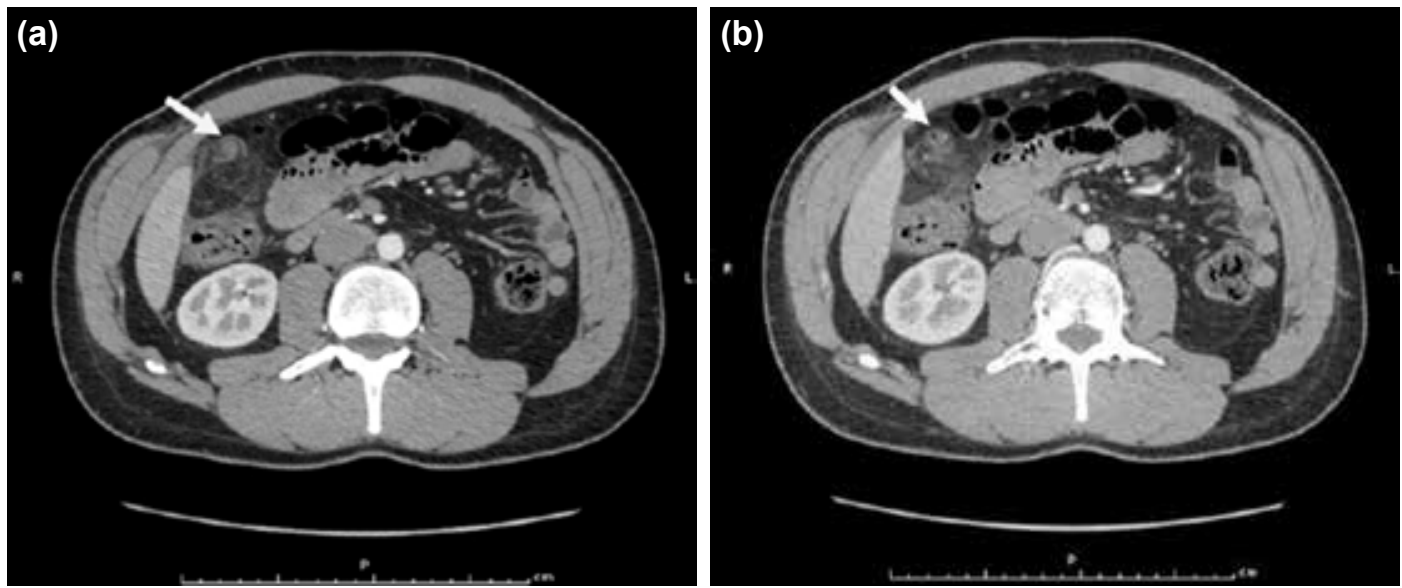

Figure 1. Contrast-enhanced abdominal CT. $(\mathbf{a}, \mathbf{b})$ Local mass of fat density in a whirling pattern at the twisted point of the omentum (arrows).
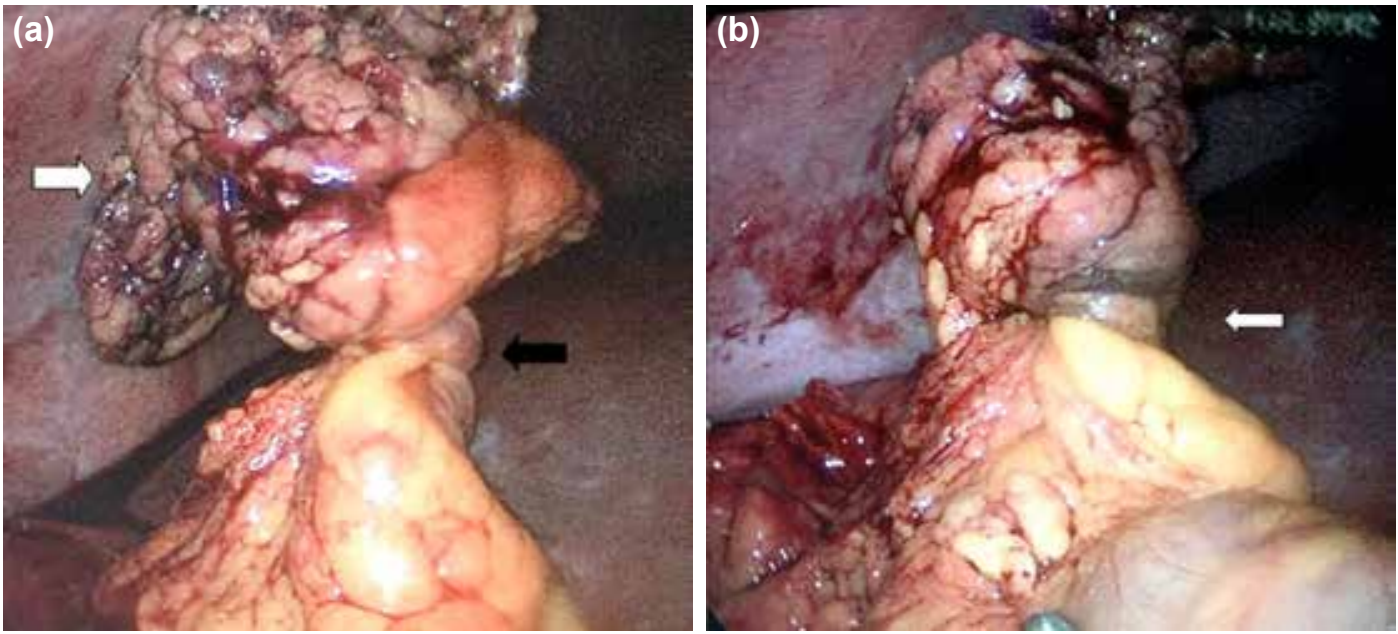

Figure 2. Intraoperative findings. (a) The right section of the greater omentum twisted twice in a clockwise direction (black arrow), and the infracted distal part of the omentum (white arrow). (b) Omental vessels twisted by torsion (arrow).

\section{DISCUSSION}

Torsion of the greater omentum is an uncommon cause of acute abdomen, accounting for $1.1 \%$ of all cases of acute abdominal pain. ${ }^{[6]}$ Omental torsion is difficult to diagnose preoperatively, and accurate preoperative diagnosis is reported in only $0.6-4.8 \%$ of cases. ${ }^{[7]}$ When compared with appendicitis, this pathology has an incidence of $0.0016-0.37 \%$, a ratio of less than 4 cases per 1000 cases of acute appendicitis. [8] Omental torsion is primarily seen in the 30-50-year age group, with male predominance. ${ }^{[1,9]}$ However, a few cases have been reported in children. ${ }^{[10]}$ Estimated incidence of primary omental torsion in children undergoing surgery for suspected appendicitis ranges between $0.024-0.1 \% .^{[9,1]}$

Omental torsion is classified as primary or secondary, the latter being far more common. ${ }^{[8]}$ Primary or idiopathic torsion is a rare condition, occurring in the absence of associated or secondary intraabdominal pathology. ${ }^{[1]}$ Eitel first described it, in 1899 , as a rare surgical cause of acute abdomen. Thus far, approximately 300 cases have been reported. Pathogenesis of primary omental torsion is considered to be wideranging. Adams classified the pathogenesis of primary torsion into "predisposing factors" and "precipitating factors." [12] Predisposing factors include obesity and anatomic variations in the arrangement of omental blood vessels. Obesity is a well-documented risk linked to primary torsion, with I study reporting that almost $70 \%$ of patients with omental infarction were obese. ${ }^{[13]}$ Precipitating factors include trauma and acute changes in body position.

Secondary torsion is more common and is associated with abdominal pathology, including inguinal hernia (the pathology most commonly associated), tumors in the omentum, cysts, intraabdominal inflammation, and post-surgical wound or scarring. ${ }^{[14]}$ Adams, ${ }^{[12]}$ and Barcia and Nelson ${ }^{[15]}$ emphasized the association between right inguinal hernia and secondary omental torsion. 
No anatomic cause or pathology, such as obesity, adhesion, or hernia, could be determined in the present patient. A precipitating factor could be identified; the patient had sustained blunt abdominal trauma (multiple falls while skiing) only 24 hours prior to onset of symptoms. For these reasons, diagnosis of primary omental torsion was made.

Pathophysiology of omental torsion involves rotation around the long axis, resulting in vascular compromise and impaired blood supply. ${ }^{[16]}$ As the torsion progresses, arterial occlusion leads to acute hemorrhagic infarction, and eventually to necrosis of the omentum. ${ }^{[14]}$ Spontaneous reduction of omental torsion has sporadically been reported. ${ }^{[1]]}$ In a large majority of reported cases, omental torsion with infarction was segmental, involving the right side of the omentum, as it is longer, heavier, and more mobile than the left side. ${ }^{[18-20]}$

Clinical picture of primary and secondary omental torsion is similar. The earliest symptom associated with omental torsion is constant nonradiating pain of increasing severity, mostly localized in the right lower quadrant. ${ }^{[2]]}$ The majority of cases present with a single episode of abdominal pain, and recurrent pain may suggest intermittent torsions. ${ }^{[22]}$ In addition, $50 \%$ of patients present with low-grade fever and moderate leukocytosis. ${ }^{[4]}$ Gastrointestinal symptoms, such as nausea, anorexia, and vomiting, are uncommon..$^{[5]}$ Physical examination reveals signs of peritoneal irritation with guarding of rebound abdominal tenderness. If a large section of the omentum is involved, a mass may be palpable. ${ }^{[3]}$

Omental torsion can mimic a variety of other acute abdominal conditions. Differential diagnosis should include acute appendicitis, cholecystitis, cecal diverticulitis, perforated duodenal ulcer, abdominal wall hematoma, and intestinal obstruction. ${ }^{[9,23]}$ In women of reproductive age, salpingitis, ovarian cyst torsion, and ectopic pregnancy should also be considered. In children, differential diagnosis should also include inflammation of the Meckel's diverticulum, as well as mesenteric adenitis. ${ }^{[9]}$ Finally, torsion of accessory spleen is another diagnostic possibility, as an accessory spleen, when present, usually resides inside the omentum.

Abdominal ultrasound is important in the exclusion of other acute conditions, and usually shows an ovoid or cake-like hyperechoic mass adherent to the peritoneum. CT scan can easily differentiate omental torsion from acute cholecystitis, appendicitis, and cecum diverticulitis. Classic signs of omental torsion on CT scan are hazy, but may include the whirl sign of a fatty mass with concentric linear strands in the greater omentum. Balthazar et al. showed that magnetic resonance imaging (MRI) was effective, even when omental torsion was complicated by bleeding or development of abscess. ${ }^{[2]]}$ However, because CT scan is the gold standard diagnostic modality in patients presenting with acute abdomen, ${ }^{[23]}$ the need for MRI to establish a diagnosis of omental torsion is rare.
Once diagnosed, omental torsion should be surgically managed. Surgical resection of the affected omentum, possibly achieved via laparoscopy, is the treatment of choice. ${ }^{[25,26]}$ Surgery may also offer definitive diagnosis, if not established preoperatively. Advantages of laparoscopy include complete examination of the abdominal cavity to confirm diagnosis, in addition to the benefits of minimal-access surgery, which include decreased postoperative pain and wound-related complications. ${ }^{[27,28]}$ Laparoscopy was presently successfully performed, without the need for open conversion.

Alternative to surgery, conservative management of omental torsion has been proposed for patients who are hemodynamically stable. ${ }^{[5]}$ In this event, oral analgesics, anti-inflammatory drugs, and prophylactic antibiotics are administered, though patient selection should include a careful imaging workup to exclude other acute abdominal pathologies. ${ }^{[29]}$ Patients conservatively treated may require extended use of analgesia, and may suffer from other complications, such as abscess formation and adhesions induced by the persistence of necrotic tissue in the abdomen. ${ }^{[2,30,31]}$ Regardless of these drawbacks, conservative management may succeed, particularly in patients with no associated complication. ${ }^{[32-34]}$

\section{Conclusion}

Primary torsion of the omentum is a rare pathology, presenting as acute abdomen and mimicking acute appendicitis in a majority of cases. Preoperative diagnosis may be difficult, but can be achieved using diagnostic imaging, particularly CT scan. Laparoscopy could be considered as the first-hand surgical option, both for differential diagnosis and treatment. Conservative treatment may be offered as an option, though only after careful selection of patients.

Conflict of interest: None declared.

\section{REFERENCES}

1. Y G, R A. Omental torsion. J Clin Diagn Res 2014;8:NE01-2.

2. Mavridis G, Livaditi E, Baltogiannis N, Vasiliadou E, ChristopoulosGeroulanos G. Primary omental torsion in children: ten-year experience. Pediatr Surg Int 2007;23:879-82. Crossref

3. Scabini S, Rimini E, Massobrio A, Romairone E, Linari C, Scordamaglia $\mathrm{R}$, et al. Primary omental torsion: A case report. World J Gastrointest Surg 2011;3:153-5. Crossref

4. Breunung N, Strauss P. A diagnostic challenge: primary omental torsion and literature review - a case report. World J Emerg Surg 2009;4:40.

5. Kerem M, Bedirli A, Mentes BB, Sakrak O, Pala I, Oguz M. Torsion of the greater omentum: preoperative computed tomographic diagnosis and therapeutic laparoscopy. JSLS 2005;9:494-6.

6. Aronsky D, Z'graggen K, Banz M, Klaiber C. Abdominal fat tissue necrosis as a cause of acute abdominal pain. Laparoscopic diagnosis and therapy. Surg Endosc 1997;11:737-40. Crossref

7. Poujade O, Ghiles E, Senasli A. Primary torsion of the greater omentum: case report-review of literature: diagnosis cannot always be performed before surgery. Surg Laparosc Endosc Percutan Tech 2007;17:54-5.

8. Pinedo-Onofre JA, Guevara-Torres L. Omental torsion. An acute abdomen etiology. [Article in Spanish] Gac Med Mex 2007;143:17-20. [Abstract] 
9. Tsironis A, Zikos N, Bali C, Pappas-Gogos G, Koulas S, Katsamakis N. Acute abdomen due to primary omental torsion: case report. J Emerg Med 2013;44:45-8. Crossref

10. Ozbey H, Salman T, Celik A. Primary torsion of the omentum in a 6-year-old boy: report of a case. Surg Today 1999;29:568-9. Crossref

11. Valioulis I, Tzallas D, Kallintzis N. Primary torsion of the greater omentum in children - a neglected cause of acute abdomen? Eur J Pediatr Surg 2003;13:341-3. Crossref

12. Adams JT. Primary torsion of the omentum. Am J Surg 1973;126:1025. Crossref

13. van Breda Vriesman AC, Lohle PN, Coerkamp EG, Puylaert JB. Infarction of omentum and epiploic appendage: diagnosis, epidemiology and natural history. Eur Radiol 1999;9:1886-92. Crossref

14. Borgaonkar V, Deshpande S, Rathod M, Khan I. Primary Omental Torsion Is a Diagnostic Challenge in Acute Abdomen-a Case Report and Literature Review. Indian J Surg 2013;75:255-7. Crossref

15. Barcia PJ, Nelson TG. Primary segmental infarction of the omentum with and without torsion. Am J Surg 1973;126:328-31. Crossref

16. Theriot JA, Sayat J, Franco S, Buchino JJ. Childhood obesity: a risk factor for omental torsion. Pediatrics 2003;112(6 Pt 1):460. Crossref

17. Saraç AM, Yeğen C, Aktan AO, Yalin R. Primary torsion of the omentum mimicking acute appendicitis: report of a case. Surg Today 1997;27:2513. Crossref

18. Puylaert JB. Right-sided segmental infarction of the omentum: clinical, US, and CT findings. Radiology 1992;185:169-72. Crossref

19. Ceuterick L, Baert AL, Marchal G, Kerremans R, Geboes K. CT diagnosis of primary torsion of greater omentum. J Comput Assist Tomogr 1987;11:1083-4. Crossref

20. Hirano Y, Oyama K, Nozawa H, Hara T, Nakada K, Hada M, et al. Left-sided omental torsion with inguinal hernia. World J Gastroenterol 2006;12:662-4. Crossref

21. López-Colombo A, Montiel-Jarquín A, García-Carrasco M, Nava A, Arcega-Domínguez A, Martínez-Fernández R, et al. Torsion of the omentum. A rare cause of acute abdomen. Rev Med Inst Mex Seguro Soc
2010;48:549-52.

22. Parr NJ, Crosbie RB. Intermittent omental torsion--an unusual cause of recurrent abdominal pain? Postgrad Med J 1989;65:114-5. Crossref

23. Naffaa LN, Shabb NS, Haddad MC. CT findings of omental torsion and infarction: case report and review of the literature. Clin Imaging 2003;27:116-8. Crossref

24. Balthazar EJ, Lefkowitz RA. Left-sided omental infarction with associated omental abscess: CT diagnosis. J Comput Assist Tomogr 1993;17:379-81. Crossref

25. Sánchez J, Rosado R, Ramírez D, Medina P, Mezquita S, Gallardo A. Torsion of the greater omentum: treatment by laparoscopy. Surg Laparosc Endosc Percutan Tech 2002;12:443-5. Crossref

26. Costi R, Cecchini S, Randone B, Violi V, Roncoroni L, Sarli L. Laparoscopic diagnosis and treatment of primary torsion of the greater omentum. Surg Laparosc Endosc Percutan Tech 2008;18:102-5. Crossref

27. Chung SC, $\mathrm{Ng} \mathrm{KW}, \mathrm{Li}$ AK. Laparoscopic resection for primary omental torsion. Aust N Z J Surg 1992;62:400-1. Crossref

28. Gassner PE, Cox MR, Cregan PC. Torsion of the omentum: diagnosis and resection at laparoscopy. Aust N Z J Surg. 1999;69:466-7. Crossref

29. Coulier B. Segmental omental infarction in childhood: a typical case diagnosed by CT allowing successful conservative treatment. Pediatr Radiol 2006;36:141-3. Crossref

30. Itenberg E, Mariadason J, Khersonsky J, Wallack M. Modern management of omental torsion and omental infarction: a surgeon's perspective. J Surg Educ 2010;67:44-7. Crossref

31. Fragoso AC, Pereira JM, Estevão-Costa J. Nonoperative management of omental infarction: a case report in a child.J Pediatr Surg 2006;41:1777-9.

32. Kepertis C, Koutsoumis G. Primary torsion of the greater omentum. Indian Pediatr 2005;42:613-4.

33. Rimon A, Daneman A, Gerstle JT, Ratnapalan S. Omental infarction in children.J Pediatr 2009;155:427-31. Crossref

34. Soobrah R, Badran M, Smith SG. Conservative management of segmental infarction of the greater omentum: a case report and review of literature. Case Rep Med 2010. Crossref

\section{OLGU SUNUMU - ÖZET}

\section{Omentum majus torsiyonunun neden olduğu akut batın:} Olgu raporu ve literatürün gözden geçirilmesi

\section{Dr. Camilla Cremonini, Dr. Andrea Bertolucci, Dr. Dario Tartaglia, Dr. Francesca Menonna, Dr. Christian Galatioto, Dr. Massimo Chiarugi}

Di Pisa Üniversitesi, Acil Cerrahi Bölümü, Pisa-Italya

Omentum majusun torsiyonu akut karının nadir bir nedenidir. Etiyopatogenezine dayanarak primer ve sekonder olarak sınıflandırılabilir. Ancak, sonuçta nedene bağlı olmaksızın segmenter veya yaygın omentum nekrozu oluşacaktır. Ameliyat öncesi tanı kolay olmamasına rağmen karının ultrason ve bilgisayarlı tomografi (BT) taramaları omentum torsiyonunu düşündüren özgün özellikleri gösterebilir. Seçilecek tedavi etkilenmiş omentumun laparoskopik rezeksiyonudur. Bu olgu sunumunda, kapsamlı literatür derlemesine ilaveten primer omentum torsiyonu bildirilmiştir.

Anahtar sözcükler: Akut batın; laparoskopi; omentum enfarktı; omentum majus; torsiyon.

Ulus Travma Acil Cerrahi Derg 2016;22(4):391-394 doi: 10.5505/tites.2015.74944 